\title{
Implications of application of brain-computer interfaces in patients with disorders of consciousness
}

\section{Implikacje wykorzystania interfejsów mózg- komputer u pacjentów z zaburzeniami świadomości}

\author{
Emilia Mikołajewska ${ }^{1}$, Dariusz Mikołajewski ${ }^{2,3}$ \\ ${ }^{1}$ Rehabilitation Clinic, Military Clinical Hospital No. 10 with Polyclinic, Powstańców Warszawy 5 , \\ 85-681 Bydgoszcz, Poland \\ ${ }^{2}$ Institute of Mechanics and Applied Komputer Science, Faculty of Mathematics, Physics and \\ Technical Sciences, Kazimierz Wielki University, Kopernika 1, 85-074 Bydgoszcz, Poland \\ ${ }^{3}$ Departament of Informatics, Faculty of Physics, Astronomy and Applied Computer Science, \\ ul. Grudziądzka 5, 87-100 Toruń, Poland \\ E-mail address: e.mikolajewska@wp.pl , darek.mikolajewski@wp.pl
}

\begin{abstract}
Disorders of consciousness belong to the most severe impairments, especially in patients with neurological deficits. Scientists look for novel solution making the breakthrough in contemporary approaches to aforementioned patients. Article aims at assessment of medical, social, economical and ethical result of introduction brain-computer interfaces to the diagnosis and therapy in patients with disorders of consciousness.
\end{abstract}

Keywords: brain computer interface; BCI; disorder of consciousness; social implications

\section{STRESZCZENIE}

Zaburzenia świadomości należą do najpoważniejszych deficytów, szczególnie u pacjentów neurologicznych. Naukowcy poszukują nowych rozwiązań mogących przynieść przełom w dotychczasowych podejściach do tej grupy pacjentów. Celem pracy jest ocena skutków medycznych, społecznych, ekonomicznych i etycznych wprowadzenia interfejs ów mózg-komputer do diagnostyki i terapii pacjentów z zaburzeniami świadomości.

Słowa kluczowe: interfejs mózg komputer, zaburzenie świadomości, implikacje społeczne. 


\section{WPROWADZENIE}

Postęp nauk medycznych oraz techniki medycznej powoduje zwiększoną przeżywalność ofiar najcięższych schorzeń i wypadków, jednak nie gwarantuje pełnego powrotu do zdrowia. Do najcięższych deficytów należą zaburzenia świadomości (ang. disorders of consciousness - DoCs).

Celem pracy jest ocena skutków medycznych, społecznych, ekonomicznych i etycznych wprowadzenia do diagnostyki i terapii pacjentów z zaburzeniami świadomości najnowszych zdobyczy techniki, jakimi są interfejsy mózg-komputer (ang. brain-computer interfaces BCIs).

\section{ZABURZENIA ŚWIADOMOŚCI JAKO PROBLEM MEDYCZNY, SPOLECZNY I EKONOMICZNY}

Zaburzenia świadomości nie stanowią obecnie wyodrębnionego zespołu chorobowego, lecz diagnozuje się je w ramach objawów schorzeń o różnej etiologii - zarówno udarów czy urazów czaszkowo mózgowych, jak również poważnych schorzeń metabolicznych i ciężkich zatruć. Ma to istotne konsekwencje:

- zaniżone i niepewne dane epidemiologiczne (np. na poziomie $5 \%$ wśród przyczyn hospitalizacji [1]), co może powodować niedocenianie tego problemu,

- problemy diagnostyczne związane z rozróżnianiem poszczególnych zaburzeń świadomości, co przekładać się może na błędne rozpoznanie i niewłaściwą terapię,

- możliwość wystąpienia szkodliwych zmian wtórnych i skutków ubocznych,

- niewłaściwe ukierunkowanie wysiłków personelu medycznego i opieki społecznej, samych pacjentów i ich rodzin/opiekunów,

- przedłużenie terapii w odniesieniu do pacjentów, których przy właściwej diagnostyce można przywrócić do aktywniejszego funkcjonowania i odpowiednio wyższej jakości życia pacjentów i ich rodzin/opiekunów,

- przysparzanie dodatkowych cierpień pacjentom,

- nieracjonalne wykorzystanie posiadanych sił i środków,

- konieczność ponoszenia dodatkowych kosztów związanych z terapią i opieką nad pacjentami z zaburzeniami świadomości.

Do najczęściej spotykanych zaburzeń świadomości należą: śpiączka (ang. coma), stan minimalnej świadomości (ang. minimally conscious state - MCS, podzielony ostatnio na MCS- oraz MCS+), stan wegetatywny (ang. vegetative state), przetrwały stan wegetatywny (ang. persistent wegetative state $=$ unresponsive weakfulness syndrome), zespół zamknięcia (ang. locked-in syndrome) [2-4].

Ogólnie, bez względu na etiologię, za pośrednią przyczynę zaburzeń świadomości uważa się zachwianie integracji funkcjonalnej znacznych obszarów układu nerwowego, w tym pnia mózgu, obszarów podkorowych i kory mózgowej. Miejsce, rozległość oraz stopień uszkodzenia sieci neuronów może wpływać nie tylko na układy związane z regulowaniem snu/czuwania, ale również bezpośrednio na obszary mózgu związane $\mathrm{z}$ funkcjami poznawczymi. Pomimo tego nawet rokowanie na podstawie wykonanej diagnostyki obrazowej obszarów układu nerwowego nie niesie ze sobą niezbędnej pewności.

Diagnostyka zaburzeń świadomości może być obarczona dużym błędem wynikającym m.in. $\mathrm{z}$ różnicy $\mathrm{w}$ doświadczeniu osób stawiających diagnozę oraz kwestie związane $\mathrm{z}$ 
obiektywną percepcją zachowania pacjenta i jego reagowania na zewnętrzne bodźce. Stąd liczb błędnych diagnoz $\mathrm{w}$ części przypadków zaburzeń świadomości może sięgać nawet kilkudziesięciu procent.

\section{MIEJSCE INTERFEJSÓW MÓZG-KOMPUTER W LECZENIU I REHABILITACJI PACJENTÓW Z ZABURZENIAMI ŚWIADOMOŚCI}

Interfejsy mózg-komputer to urządzenia elektroniczne wykorzystujące pomiary (najczęściej dokonywane $\mathrm{w}$ czasie rzeczywistym) aktywności elektrofizjologicznej ośrodkowego układu nerwowego (np. sygnałów bioelektrycznych mózgu takich jak elektroencefalogram - EEG) do pozamięśniowej komunikacji człowieka z otoczeniem $[5,6]$. Umożliwiają one niemal bezpośrednie wykorzystanie informacji z układu nerwowego pacjenta do diagnostyki, komunikacji, a nawet sterowania specjalnie dedykowanymi urządzeniami. Wykorzystanie interfejsów mózg-komputer może stanowić jedyną szansę dla pacjenta $\mathrm{z}$ zburzeniem świadomości $\mathrm{z}$ (częściowo) zachowanymi funkcjami mózgu na prawidłowe zdiagnozowanie stanu zdrowia oraz wczesne podjęcie właściwej terapii. $Z$ badań wynika, że jest to możliwe wszystkich pacjentów ze wszystkimi zaburzeniami świadomości z wyjątkiem całkowitego zespołu zamknięcia (ang. completely locked-in-syndrome - CLIS) $[7,8]$. Co więcej - terapia $\mathrm{z}$ wykorzystaniem BCI może pozwolić na stymulację neuroplastycznosci układu nerwowego poprzez odpowiednio dobrane zadania funkcjonalne (od prostych zadań związanych np. z wyobrażaniem czynności czy orientacją przestrzenną aż po złożone procesu planowania ruchu przygotowujące do instalacji neuroprotezy ruchowej). $\mathrm{Na}$ dzień dzisiejszy trudno jednoznacznie postawić granicę takiemu funkcjonalnemu powrotowi do zdrowia [9-11].

Brak ujednolicenia rozwiązań technicznych oraz zróżnicowanie etiologii i stanu funkcjonalnego pacjentów powoduje to, że należy stworzyć metodologię badań klinicznych w oparciu o BCI wychodzącą od podstawowych urządzeń o sposobie sterowania najprostszym dla pacjenta (zarówno samej obsługi, jak i jej zrozumienia i nauki), oraz (rozbudowie miarę postępów pacjenta) stopniowej rozbudowie ww. rozwiązań do bardziej złożonych systemów. Pozwoli to na indywidualne dopasowanie dedykowanego rozwiązania do rzeczywistych potrzeb i możliwości pacjenta, jego terapeutów i opiekunów. Wymaga to jednak szeregu dalszych badań, dopracowania istniejących rozwiązań oraz sprawdzenia potencjalnych rozwiązań alternatywnych i przyszłościowych, opracowania powtarzalnych i bezpiecznych procedur klinicznych w obszarach: przygotowania i edukacji pacjentów i innych uczestników procesu terapeutycznego, implantacji i dostrajania interfejsów oraz towarzyszących im urządzeń, a także przeciwdziałania możliwym szkodliwym zmianom wtórnym i skutkom ubocznym.

Warto zaznaczyć, że pierwszy komercyjny medyczny interfejs mózg-komputer oparty na wykorzystaniu EEG - Wadsworth BCI System - jest już w klinicznym użyciu w USA.

\section{KIERUNKI DALSZYCH BADAŃ ORAZ ICH MOŻLIWE DO PRZEWIDZENIA KONSEKWENCJE}

Bez wątpienia zasadnicze kierunki rozwoju obejmują:

1. w obszarze nauk technicznych:

- badania nad dalszym rozwojem dotychczas wykorzystywanych technik do diagnostyki, komunikacji i sterowania, w tym sterowania komputerami, 
sztucznymi kończynami czy całymi złożonymi systemami, np. inteligentnego domu (ang. smart home) czy inteligentnego ubrania (ang. i-wear),

- opracowanie standardów technicznych oraz procedur doboru sprzętu,

- rozwój rozwiązań miniaturowych oraz zupełnie bezinwazyjnych, takich jak interfejsy mózg-komputer oparte na magnetoencefalografii (MEG),

2. w obszarze nauk medycznych:

- badania na większych grupach pacjentów z różnymi zaburzeniami świadomości o różnych etiologiach,

- wypracowanie wytycznych klinicznych, wskazań i przeciwwskazań oraz przygotowanie personelu o różnych specjalnościach tworzącego wielodyscyplinarne zespołu terapeutyczne,

- zbadanie bezpieczeństwa użytkowania oraz długoterminowych efektów wykorzystania interfejsów mózg-komputer oraz ich wpływ na możliwość potencjalnego przejścia do innych form komunikacji czy sterowania,

- włączenie wykorzystania interfejsów mózg-komputer w ramach terapii holistycznej $\mathrm{i}$ biopsychospołecznego podejścia $\mathrm{W}$ terapii pacjentów $\mathrm{Z}$ zaburzeniami świadomości (w tym w rehabilitacji i opiece domowej).

Kierunki dalszych badań dotyczą jednak nie tylko nauk medycznych i technicznych, ale również społecznych i humanistycznych. W tym obszarze szersze wprowadzenie interfejsów mózg-komputer może spowodować:

- pojawienie się większej grupy pacjentów „,wybudzonych” (również: po wielu latach), wymagających odrębnego podejścia terapeutycznego, w tym ze strony psychologów, oraz dedykowanych rozwiązań np. w dziedzinie nauczania,

- wzrost znaczenia społeczeństwa informacyjnego w grupie osób niepełnosprawnych dzięki przeniesieniu części komunikacji oraz aktywności społecznej (forów internetowych, grup wsparcia, blogów, itp.) do mediów elektronicznych,

- szerszy dotarcie poglądów i doświadczeń osób z najcięższymi deficytami do opinii społecznej, przekładające się na zmianę wizerunku osoby niepełnosprawnej i osoby z zaburzeniami świadomości (por. odbiór społeczny filmu „Motyl i skafander”) oraz wypracowanie bardziej restrykcyjnych zasad etycznych w obszarze zarówno terapii i opieki w tej grupie pacjentów, ale również w obszarze kryteriów orzekania śmierci,

- zmniejszenie problemu wypalenia zarówno u specjalistów medycznych i opieki społecznej, jak i rodzin pacjentów.

Nie można również nie dostrzegać zagrożeń związanych $\mathrm{z}$ dehumanizacją medycyny, bezpieczeństwem użytkowania czy trudnymi do przewidzenia zmianami długotrwałego układzie nerwowym pacjentów wynikającymi $z$ długotrwałego użycia BCI. Również wykorzystanie BCI u pacjentów pediatrycznych z zaburzeniami świadomości obarczone będzie znacznie większym ryzykiem niż u pacjentów dorosłych.

Zmiany te, chociaż stopniowe, mogą się nakładać ze zmianami związanymi m.in. ze spodziewanym starzeniem się społeczeństw krajów rozwiniętych, potęgując ich efekt. Rzetelna analiza ich możliwych skutków może przełożyć się na lepsze przygotowanie kadr inżynierskich, medycznych i opieki społecznej, rozwój dedykowanych rozwiązań organizacyjnych i technicznych, oraz zmniejszenie potencjalnych kosztów ekonomicznych wprowadzenia niezbędnych zmian systemowych. 


\section{WNIOSKI}

Rozwój nowoczesnych technologii medycznych, szczególnie dedykowanych pacjentom z najcięższymi deficytami, może nieść ze sobą ważne zmiany nie tylko w praktyce klinicznej, ale również w sferze społecznej i etycznej. Wczesne ich dostrzeżenie ułatwi ich analizę, reagowanie oraz wskazanie właściwych kierunków niezbędnych zmian.

\section{References}

[1] Henry G. L., Little N., Jagoda A., Neurologic emergencies, $3^{\text {rd }}$ ed, (2010) New York, McGraw Hill.

[2] Monti M. M., Owen A. M., Journal of Psychophysiology 24 (2010) 76-82

[3] Monti M. M., Laureys S., Owen A. M., British Medical Journal 341 (2010) 292-296.

[4] Laureys S., Antoine S., Boly M., Acta Neurologica Belgica 102 (2002) 177-185.

[5] Mikołajewska E., Mikołajewski D., Niepełnosprawność - zagadnienia, problemy, rozwiazania, III/2012(4) (2012) 19-36.

[6] Naci WSP., Monti M. M., Cruse D., Annals of Neurology 72(2012) 312-23.

[7] Kübler A., Birbaumer N., Clinical Neurophysiology 119(11) (2008) 2658-2666.

[8] Birbaumer N., Cohen L. G., Journal of Physiology 579 (2007) 621-636.

[9] Liberati G., Birbaumer N., Cognitive Processing 13 Suppl. 1 (2012) 239-241.

[10] Cruse D., Chennu S., Chatelle C., Neurology 78(11) (2012) 816-822.

[11] Kübler A., Furdea A., Halder S., Annals of the New York Academy of Sciences, 1157 (2009) 90-100. 